Formatif: Jurnal Ilmiah Pendidikan MIPA

Vol. 8, No. 1, April 2018, pp. 57-68

p-ISSN: 2088-351X

e-ISSN: 2502-5457

DOI: http://dx.doi.org/10.30998/formatif.v8i1.2365

\title{
Potential Local Physics Based Learning of Jepara District To Improve Science Process Skills and Students Entrepreneurship
}

\author{
Pembelajaran Fisika Berbasis Potensi Lokal Kabupaten Jepara Untuk \\ Meningkatkan Keterampilan Proses Sains dan Jiwa Kewirausahaan Peserta Didik
}

\author{
Ahmad Khoiri (*) \\ Pendidikan Fisika Universitas Sains Al-Qur'an Jawa Tengah di Wonosobo
}

\author{
Almira Syifa \\ Nurul Mubin \\ Universitas Sains Al-Qur'an Jawa Tengah di Wonosobo
}

Received: March 17, 2018

Revised: March 30, 2018

Accepted: April 4, 2018

\begin{abstract}
Physics-based learning of local potentials on simple plan materials as a source of learning the art of carving through levers, incline, pulley and wheel pivot, learning that equip knowledge about the potentials become benchmarks and reference in developing Jepara regency. Design research using One Group Pretest-Postest Design. Analysis included: normality and homogeneity, $\mathrm{t}$-test hypothesis and gain test. Based on the result of ttest $\left(\mathrm{t}_{\text {hitung }}<\mathrm{t}_{\text {tabel }}=0.0057<2,00\right)$ there is difference of Science Process Skills before and after physics learning based on local potency and gain test result there is an increase of 0.347 is moderate category. In the aspect of entrepreneurship spirit obtained an average of $83.3 \%$ good category, local Potential has been studied raises the spirit of fanaticism and high loyalty to a strong sense of ownership so as to contribute positively to the Science Process Skills and entrepreneurial enthusiasm of learners through indicators: confidence; task-oriented and results; dare to take risks; spirited leadership; thinking toward outcomes (benefits) and originality.
\end{abstract}

Keywords: Potential Local, Science Process Skills, Entrepreneurship

(*) Corresponding Author: $\quad$ E-mail: akhoiri@unsiq.ac.id - 08562566827

How to Cite: Khoiri, A., Syifa, A., \& Mubin, N. (2018). Potential local physics based learning of Jepara District to improve science process skills and students entrepreneurship. Formatif: Jurnal Ilmiah Pendidikan MIPA, 8 (1): 57-68. http://dx.doi.org/10.30998/formatif.v8i1.2365

\section{PENDAHULUAN}

Potensi lokal merupakan potensi sumber daya spesifik yang dimiliki suatu daerah yang dapat dikembangkan untuk membangun kemandirian nasional. Potensi lokal tidak terlepas dari budaya, mengenai cara pandang hidup masyarakat setempat yang berhubungan dengan keyakinan, produktivitas, pekerjaan, makanan pokok, kreativitas, nilai, dan norma (Leo Agung, 2015). Suasana dan lingkungan belajar yang kondusif untuk pembelajaran fisika akan lebih tepat jika mengoptimalkan local genius, kearifan lokal atau keunggulan lokal. Faktanya nilai-nilai kearifan lokal diabaikan dalam berbagai pembelajaran, termasuk pembelajaran sains maupun fisika (Zuhdan, K.P, 2013). Potensi lokal berkembang dari tradisi kearifan yang dimiliki oleh suatu masyarakat yang bersahaja sebagai bagian dari kebudayaannya (Ihat Halimah, 2006). 
Formatif: Jurnal Ilmiah Pendidikan MIPA

Vol. 8, No. 1, April 2018, pp. 57-68

p-ISSN: 2088-351X

e-ISSN: 2502-5457

DOI: http://dx.doi.org/10.30998/formatif.v8i1.2365

Potensi lokal dapat melatih dan menumbuhkan kemampuan fisika dalam mengembangkan rasa ingin tahu peserta didik yang dapat diketahui melalui keterampilan proses sains (Fajar, M, et.al, 2015), Belajar merupakan tindakan dan perilaku peserta didik yang kompleks diperoleh dari sesuatu yang ada di lingkungan sekitar atau hal-hal yang dijadikan bahan belajar (Dimyati, et.al, 2009). Proses pembelajaran harus menekankan pada pemberian pengalaman langsung untuk mengembangkan kompetensi, agar menjelajahi dan memahami lebih mendalam tentang alam sekitar secara ilmiah (BSNP, 2006). Salah satu cara menggali pengalaman belajar fisika menggunakan potensi lokal sebagai basis pembelajaran. Hal ini, sesuai dengan lingkungan belajar di Kabupaten Jepara yang kaya akan potensi lokal.

Kabupaten Jepara merupakan daerah pantai sepanjang $82,73 \mathrm{~km}$, kondisi geografis yang bervariasi mempunyai sumber alam yang cukup melimpah. Komoditas ekspor memberikan kontribusi cukup besar yaitu mebel atau furniture, barang dari plastik dan produk anyaman serta produk nasional berupa seni ukir jepara (BBMPPT, 2012) menunjukkan bahwa daerah yang kaya potensi lokal dan dapat diimplementasikan dalam pembelajaran fisika.

Keterampilan-keterampilan mendasar dikenal dengan istilah keterampilan proses (Shinta, 2009). Keterampilan- keterampilan proses yang dikaji dalam penelitian meliputi hal sebagai berikut, mengamati, merumuskan masalah, merumuskan hipotesis, merencanakan percobaan dan melaksanakan percobaan, menganalisis, menyimpulkan dan, menerapkan konsep tentang seni ukir. Pembelajaran IPA Fisika di SMP/MTs menekankan pada pemberian pengalaman belajar secara langsung melalui penggunaan dan pengembangan keterampilan proses dan sikap ilmiah (BSNP, 2012). Selain keterampilan proses sains penting dalam sebuah pembelajaran yang dapat menumbuhkan minat jiwa kewirausahaan peserta didik untuk mempersiapkan di masa yang akan datang.

Menteri Koperasi dan UKM Syarifudin Hasan dalam Suparyanto (2012) menyatakan jumlah penduduk Indonesia mencapai 238 juta jiwa. Namun, jumlah wirausahawan hanya mencapai $0,24 \%$, Indonesia membutuhkan peningkatan wirausahawan muda untuk memperkuat ekonomi bangsa. Motivasi untuk menjadi wirausaha di Indonesia masih rendah, sebagian besar berwirausaha menjadi pilihan kedua seseorang ketika karier yang diinginkan tidak mampu dicapai, untuk menjembatani masalah yang terjadi, sangat penting di dalam pembelajaran fisika untuk memberikan ideide kreatif tentang jiwa kewirausahaan seni ukir sebagai potensi lokal di Kabupaten Jepara. Indonesisa harus segera menyiapkan SDM yang kompetitif dan berkualitas global (Aries Aniesa, 2016).

Potensi lokal yang menjadi roda ekonomi warisan leluhur jepara adalah seni ukir. Kegiatan mengukir mengandung pengetahuan tentang materi pesawat sederhana. Mengukir membutuhkan ketepatan dan keakuratan agar pola yang diinginkan dapat terukir dengan indah, beberapa jenis pesawat sederhana digunakan yaitu Bidang Miring Tuas, Katrol, dan Roda Berporos. Kekhawatiran akan kelangsungan hidup seni ukir perlu dilestarikan seiring motivasi pemuda yang semakin berkurang (Sukardi, 2016). Akibatnya, generasi muda lebih memilih bekerja di pabrik dibandingkan sebagai pengukir (Murianews, 2016). Padahal seni ukir terbukti dapat memberikan kontribusi terbesar sektor kayu olahan yang sejak 1998 menjadi pilar utama pembentukan struktur PDRB Jepara dengan share 28,06\% (Hadi Priyatno, 2016). Menunjukkan pentingnya menumbuhkan jiwa kewirausahaan peserta didik untuk meningkatkan taraf hidup dan pemberdayaan budaya Jepara.

Kurikulum muatan lokal Kabupaten Jepara sebagaimana dimaksud dalam pasal 25 ayat (3) untuk satuan pendidikan SMP/MTs, SMA/MA adalah keterampilan ukir (Perda Kab Jepara, 2011). Namun, dalam praktiknya terdapat hambatan tentang kebijakan kepala 


\section{Formatif: Jurnal Ilmiah Pendidikan MIPA}

Vol. 8, No. 1, April 2018, pp. 57-68

p-ISSN: 2088-351X

e-ISSN: 2502-5457

DOI: http://dx.doi.org/10.30998/formatif.v8i1.2365

sekolah, silabus, prasarana pembelajaran, dan bahkan keterbatasan kompetisi guru (Hadi Priyatno, 2014). Pembelajaran Fisika berbasis potensi lokal secara langsung membantu pemberdayaan peraturan daerah yang implikasinya untuk peningkatan mutu sumber daya manusia di Kabupaten Jepara. SMPN 6 Jepara yang menjadikan keterampilan ukir sebagai muatan lokal sehingga peserta didik sudah memiliki bekal kemampuan dan pengetahuan mengukir.

\section{METODE}

Penelitian ini menggunakan metode kuantitatif untuk mengetahui hubungan antara tiga variabel yaitu pembelajaran Fisika berbasis potensi lokal, keterampilan proses sains, dan jiwa kewirausahaan peserta didik kelas VIII SMPN 6 Jepara. Desain penelitian menggunakan One Grup Pretest-Postest Design. Observasi yang dilakukan sebelum eksperimen $\left(\mathrm{O}_{1}\right)$ disebut pre-test, dan sesudah eksperimen $\left(\mathrm{O}_{2}\right)$ disebut post-test.

Tabel 1. Desain Penelitian

\begin{tabular}{ccc}
\hline Pre-Test & Eksperimen (Variabel Bebas) & Post-Test \\
\hline $\mathbf{O}_{1}$ & $\mathrm{X}$ & $\mathrm{O}_{2}$ \\
\hline
\end{tabular}

$\mathrm{O}_{1} \quad$ : Pre-Test dilakukan sebelum perlakuan

$\mathrm{X} \quad$ : Perlakuan berupa pembelajaran fisika menggunakan potensi lokal materi pesawat sederhana

$\mathrm{O} 2$ : Post-Test dilakukan sebelum perlakuan

\section{Uji Normalitas}

Uji normalitas digunakan untuk mengetahui normal tidaknya distribusi pada data sampel. Uji normalitas digunakan rumus Chi-Kuadrat (Sugiyono, 2010). Kriteria berdistribusi normal jika $\mathrm{x}^{2}{ }_{\text {hitung }}<\mathrm{x}^{2}$ tabel pada taraf signifikan $(\alpha) 1 \%$, dimana $\mathrm{x}^{2}$ tabel dari peluang $(\alpha-1)$ dan derajat kebebasan $=(\mathrm{n}-1)$ dari daftar tabel distribusi chi kuadrat.

\section{Uji Homogenitas}

Uji prasyarat analisis untuk menentukan rumus t-test varians kedua sampel homogen atau tidak. Pengujian homogenitas varians digunakan uji F (Sugiyono, 2010).

\section{Uji hipotesis}

Persamaan t-test digunakan untuk menguji hipotesis komparatif dua sampel berkorelasi (Sugiyono, 2010).

\section{Uji Gain}

Uji gain digunakan untuk mengetahui seberapa besar peningkatan sebelum dan sesudah perlakuan pembelajaran berbasis potensi lokal, persamaan yang digunakan,

$\langle\mathrm{g}\rangle=\frac{\text { Skor posttest }- \text { Skor pretest }}{\text { Skor Maksimal }- \text { Skor pretest }}$.

Hake menjelaskan kategori gain standar sebagai berikut,

$$
\begin{array}{ll}
<\mathrm{g}>\geq 0.7 & \text { : gain } \text { tinggi } \\
0.3 \leq<\mathrm{g}>\leq 0.7 & \text { : gain } \text { sedang } \\
<\mathrm{g}><0.3 & \text { : gain } \text { rendah }
\end{array}
$$


Formatif: Jurnal Ilmiah Pendidikan MIPA

Vol. 8, No. 1, April 2018, pp. 57-68

p-ISSN: 2088-351X

e-ISSN: 2502-5457

DOI: http://dx.doi.org/10.30998/formatif.v8i1.2365

\section{HASIL DAN PEMBAHASAN}

\section{Hasil}

Penelitian dilakukan setelah semua instrumen lengkap dan digunakan untuk penelitian. Data yang diperoleh nilai pre test dan post test keterampilan proses sains peserta didik, skor observasi aspek-aspek keterampilan proses sains (KPS) peserta didik, dan hasil skor angket jiwa kewirausahaan peserta didik.

\section{Data Hasil pre test KPS Peserta Didik}

Sebelum pembelajaran berbasis potensi lokal dilaksanakan, peserta didik mengerjakan soal pre test berorientasi keterampilan proses sains (KPS) materi pesawat sederhana yang disajikan pada Tabel 2.

Tabel 2. Distribusi Frekuensi Nilai pre test KPS

\begin{tabular}{ccc}
\hline No & Interval & F \\
\hline 1 & $30-37$ & 2 \\
2 & $38-45$ & 4 \\
3 & $46-53$ & 7 \\
4 & $54-61$ & 10 \\
5 & $62-69$ & 5 \\
6 & $70-78$ & 6 \\
7 & $79-86$ & 2 \\
\hline
\end{tabular}

Data Hasil Post test KPS Peserta Didik

Tabel 3. Distribusi Frekuensi Nilai Post test KPS

\begin{tabular}{ccc}
\hline No & Interval & F \\
\hline 1 & $50-56$ & 5 \\
2 & $57-63$ & 2 \\
3 & $64-70$ & 10 \\
4 & $71-77$ & 8 \\
5 & $78-84$ & 5 \\
6 & $85-92$ & 5 \\
7 & $93-99$ & 1 \\
\hline
\end{tabular}

\section{a. Data Hasil Observasi Aspek KPS Peserta Didik}

Data hasil observasi keterampilan proses sains peserta didik diperoleh selama pembelajaran berbasis potensi lokal berlangsung. Lembar observasi dan rubrik penilaiaan memberi skor setiap pertemuan. Berikut data hasil observasi delapan aspek keterampilan proses sains:

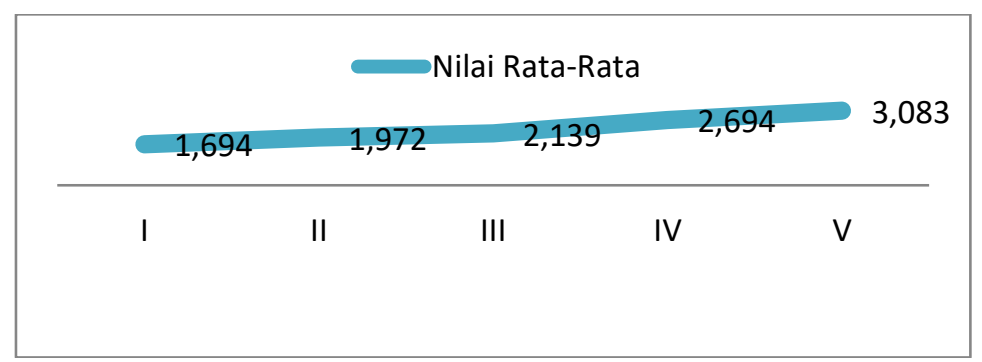

Gambar 1. Peningkatan Aspek KPS "Mengamati” 
Formatif: Jurnal Ilmiah Pendidikan MIPA

Vol. 8, No. 1, April 2018, pp. 57-68

p-ISSN: 2088-351X

e-ISSN: 2502-5457

DOI: http://dx.doi.org/10.30998/formatif.v8i1.2365

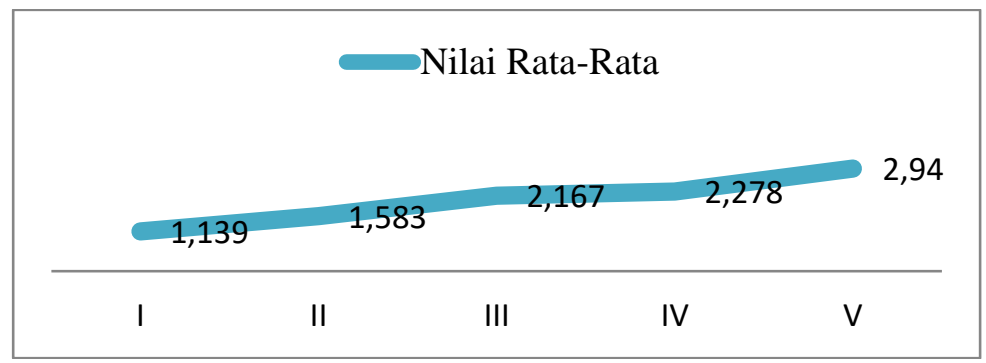

Gambar 2. Peningkatan Aspek KPS “Merumuskan Masalah”

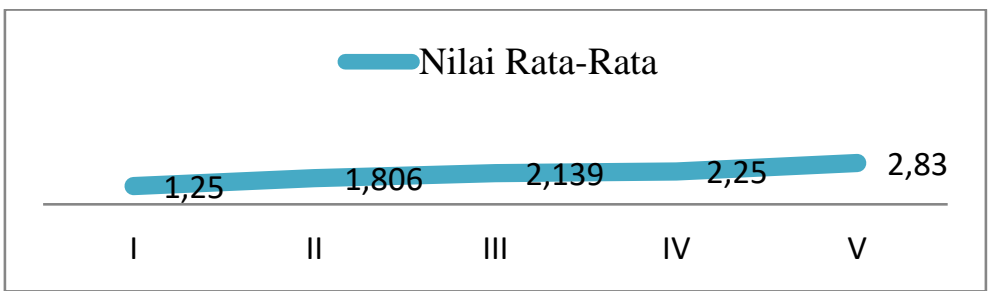

Gambar 3. Peningkatan Aspek KPS "Merumuskan Hipotesis"

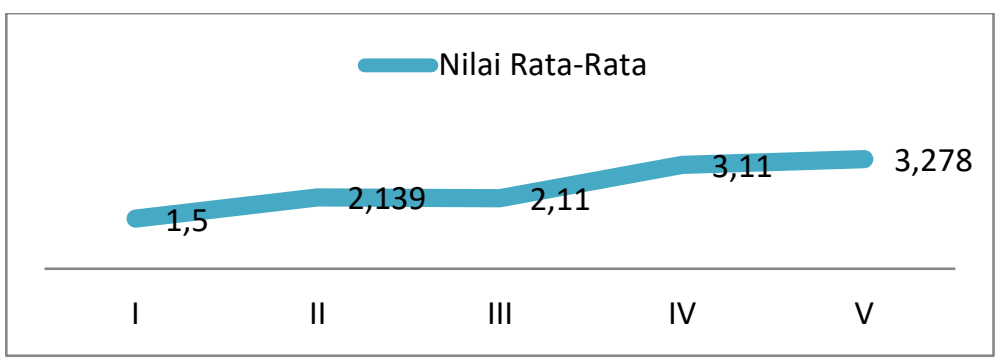

Gambar 4. Peningkatan Aspek KPS “Merencanakan Percobaan"

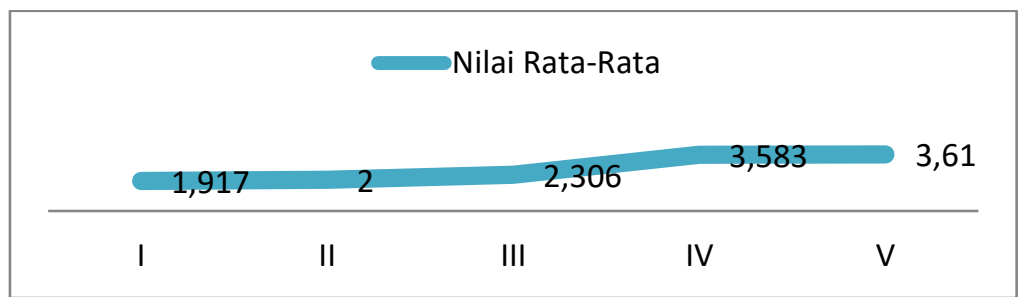

Gambar 5. Peningkatan Aspek KPS "Melaksanakan Percobaan"

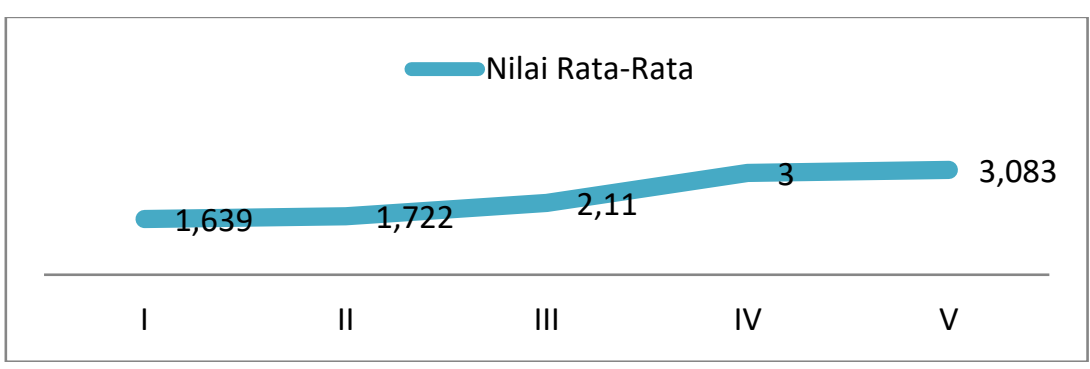

Gambar 6. Peningkatan Aspek KPS "Menganalisis Hasil Percobaan” 
Formatif: Jurnal Ilmiah Pendidikan MIPA

Vol. 8, No. 1, April 2018, pp. 57-68

p-ISSN: 2088-351X

e-ISSN: 2502-5457

DOI: http://dx.doi.org/10.30998/formatif.v8i1.2365

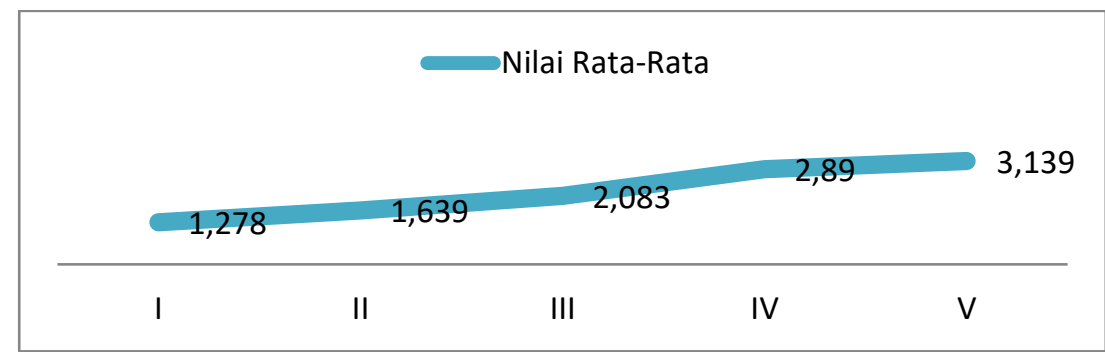

Gambar 7. Peningkatan Aspek KPS “Menyimpulkan dan Mengomunikasikan”

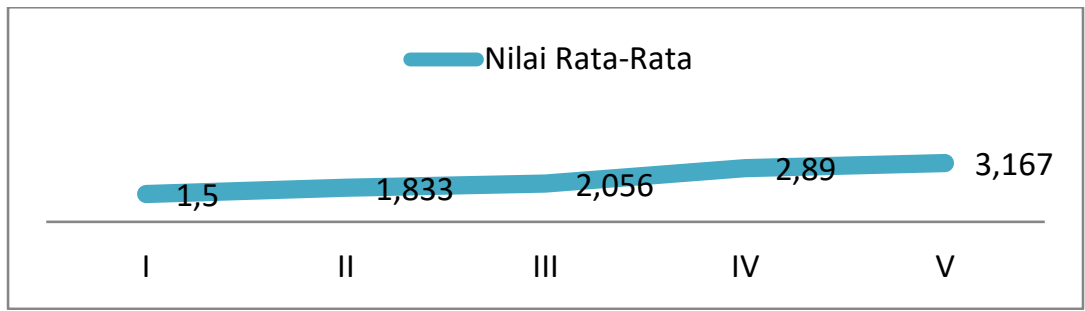

Gambar 8. Peningkatan Aspek KPS "Menerapkan Konsep"

\section{Data Hasil Angket Jiwa Kewirausahaan Peserta Didik}

Terdapat angket jiwa kewirausahaan peserta didik berjumlah 30 butir pertanyaan pada 6 aspek yaitu, (1) Percaya diri, (2) Berorientasi pada tugas dan hasil, (3) Berani mengambil risiko, (4) Berjiwa kepemimpinan, (5) Berpikir ke arah hasil (manfaat); dan (6) Keorisinilan (Meredith dalam Suprojo Pusposutardjo, 2010). Dapat disajikan dalam Tabel 4.

Tabel 4. Hasil Persentase Jawaban Angket Jiwa Kewirausahaan

\begin{tabular}{llll}
\hline No & Aspek Jiwa & Indikator & Persentase \\
& Kewirausahaan & & \\
\hline 1. & Percaya diri & - Bekerja penuh keyakinan & $90.4 \%)$
\end{tabular}

Tidak ketergantungan dalam melakukan pekerjaan

2. Berorientasi pada Memenuhi kebutuhan akan prestasi tugas dan hasil

Orientasi pekerjaan berupa laba, tekun dan tabah, tekad kerja keras.

Berinisiatif

3. Berani mengambil Berani dan mampu mengambil risiko kerja risiko

Menyukai pekerjaan yang menantang

4. Berjiwa

Kepemimpinan

Bertingkah laku sebagai pemimpin yang terbuka terhadap saran dan kritik.

Mudah bergaul dan bekerjasama dengan orang lain

5. Berfikir ke arah Kreatif dan Inovatif hasil (manfaat)

Luwes dalam melaksanakan pekerjaan

Mempunyai banyak sumberdaya

Serba bisa dan berpengetahuan luas

6. Keorisinilan

Berfikiran menatap ke depan

Perspektif 
Formatif: Jurnal Ilmiah Pendidikan MIPA

Vol. 8, No. 1, April 2018, pp. 57-68

p-ISSN: 2088-351X

e-ISSN: 2502-5457

DOI: http://dx.doi.org/10.30998/formatif.v8i1.2365

\section{Uji Hipotesis}

Hasil analisis uji t sampel berkorelasi diperoleh data sebagai berikut,

Tabel 5. Hasil Uji t Sampel Berkorelasi pre test dan post test

\begin{tabular}{llc}
\hline Rata-rata & $\overline{x_{1}}=58.056$ & $\overline{x_{2}}=72.693$ \\
\hline Simpangan Baku & $\mathrm{S}_{1}=12.89$ & $\mathrm{~S}_{2}=10.83$ \\
Varians & $\mathrm{S}_{1}{ }^{2}=166.11$ & $\mathrm{~S}_{2}{ }^{2}=117.34$ \\
$\mathrm{t}_{\text {tabel }}$ & & 2.00 \\
$\mathrm{t}_{\text {hitung }}$ & & 0.0057 \\
\hline
\end{tabular}

Berdasarkan hasil uji t sampel berkorelasi yang disajikan pada tabel diatas, diperoleh hasil $\mathrm{t}_{\text {hitung }}=0.0057$ dan $\mathrm{t}_{\text {tabel }}=2$. Karena $\mathrm{t}_{\text {hitung }}<\mathrm{t}$ tabel, terdapat perbedaan sebelum dan sesudah pembelajaran berbasis potensi lokal.

Setelah dilakukan pre-test dan post-test, maka untuk mengetahui besarnya peningkatan ketercapaian keterampilan proses sains 36 peserta didik maka dilakukan uji gain. Hasil analisis uji gain disajikan pada Tabel 6.

Tabel 6. Hasil Uji Gain Nilai pre test dan post test KPS

\begin{tabular}{clccc}
\hline No & Komponen & \multicolumn{3}{c}{ Kelas Eksperimen } \\
\cline { 3 - 5 } & & pre-test & post-test & $\langle\mathrm{g}\rangle$ \\
\hline 1 & Nilai Tertinggi & 85 & 95 & 0.66 \\
2 & Nilai Terendah & 30 & 50 & 0.286 \\
3 & Rata-Rata & 58.056 & 72.693 & 0.347 \\
\hline
\end{tabular}

Berdasarkan tabel 6 analisis skor rata-rata gain standar $(\langle\mathrm{g}\rangle)$ diperoleh nilai ratarata gain standar KPS peserta didik sebesar 0.343 berada pada kategori sedang. Berikut grafik perbandingan nilai rata-rata pre-tets dan post-test KPS:

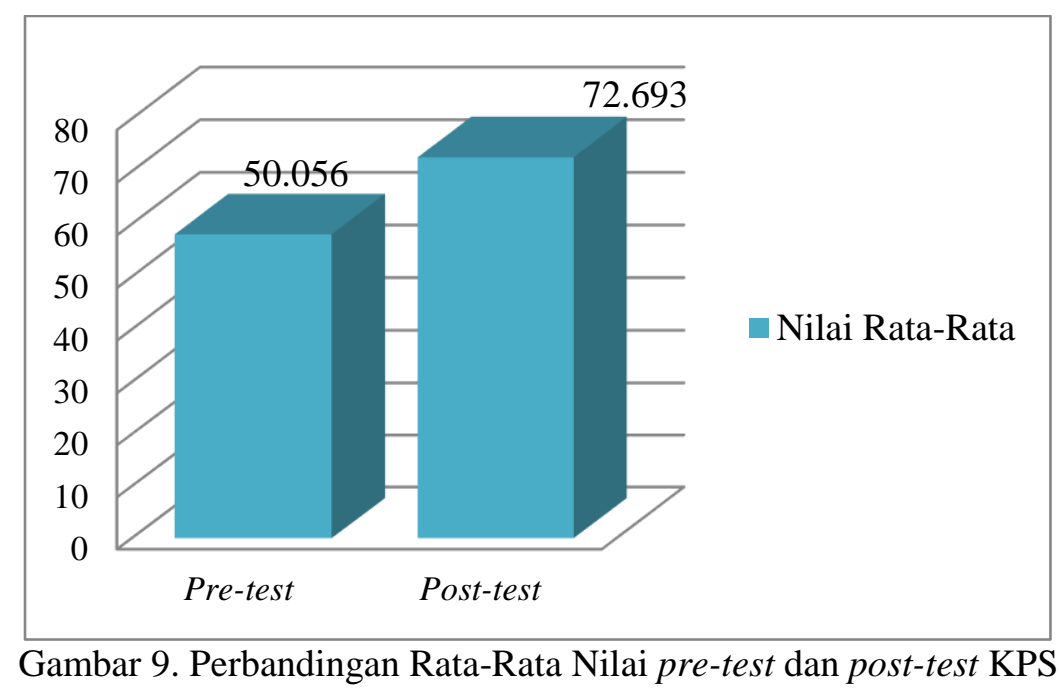

Berdasarkan hasil analisis uji t sampel berkorelasi dan uji gain menunjukkan peningkatan keterampilan proses sains peserta didik pada pembelajaran Fisika berbasis potensi lokal materi pesawat sederhana, dari hasil uji signifikansi diperoleh thitung $=0.0057$ dan $t_{\text {tabel }}=2$ dengan taraf signifikansi $\alpha=0,05$, karena $t_{\text {hitung }}<t_{\text {tabel }}=0.0057<2$, maka 
Formatif: Jurnal Ilmiah Pendidikan MIPA

Vol. 8, No. 1, April 2018, pp. 57-68

p-ISSN: 2088-351X

e-ISSN: 2502-5457

DOI: http://dx.doi.org/10.30998/formatif.v8i1.2365

terdapat perbedaan sebelum dan sesudah pembelajaran berbasis potensi lokal. Berdasarkan perhitungan uji gain diperoleh nilai rata-rata standar gain KPS peserta didik sebesar 0.343 berada pada kategori sedang.

\section{Pembahasan}

Hasil perhitungan chi kuadrat diporelah $X^{2}{ }_{\text {hitung }}$ pre-test sebesar 13.402 dan $X^{2}{ }_{\text {hitung }}$ post test sebesar 16.21. Dengan $\mathrm{N}=36$ dan taraf signifikansi $1 \%$ maka $X_{\text {tabel }}^{2}=16.812$. Karena $X^{2}$ hitung pre-test dan post-test lebih besar dari harga nilai $X_{\text {tabel }}^{2}$ maka pre test dan post test berdistribusi normal. Hasil analisis uji $\mathrm{F}$ diperoleh $\mathrm{F}_{\text {Hitung }}$ pre test sebesar 1.358 dan $\mathrm{F}_{\text {Hitung }}$ post test sebesar 1.342. Sedangkan $\mathrm{F}_{\text {Tabel }}$ pre-test sebesar 2.56 dan $\mathrm{F}_{\text {Tabel }}$ post test sebesar 2.90. Dengan taraf signifikansi $5 \%$ dan $\mathrm{dk}=\mathrm{n}-1$, karena $\mathrm{F}_{\text {Hitung }}>\mathrm{F}_{\text {Tabel }}$ maka pre test dan post test homogen.

Berdasarkan Tabel 5 hasil uji t berkorelasi terdapat perbedaan KPS peserta didik sebelum dan sesudah pembelajaran berbasis potensi lokal. Taraf signifikansi $\alpha=0,05$ $\mathrm{t}_{\text {hitung }}<\mathrm{t}_{\text {tabel }}=0.0057<2.00$. Uji gain KPS peserta didik sebesar 0.347 berada pada kategori sedang. Hasil perhitungan tersebut juga didukung dengan hasil observasi keterampilan proses sains selama pembelajaran dengan potensi lokal berlangsung diperoleh data nilai rata-rata aspek keterampilan proses setiap pertemuan mengalami peningkatan (lihat gambar 1 s.d. 8) menunjukkan keterampilan merumuskan hipotesis paling rendah dan keterampilan melaksanakan percobaan paling tinggi, alasannya bahwa peserta didik belum terbiasa merumuskan hipotesis dan berpikir ilmiah menggunakan prosedur sains dalam pembelajaran Fisika. Akan tetapi, dalam melaksanakan percobaan siswa sudah terbiasa dan dibekali pengetahuan mengukir sebelumnya melalui kegiatan ekstrakurikuler mengukir, siswa lebih mudah melakukan dan mempraktikan secara langsung dari pada harus mengonsep dan menghipotesiskannya.

Keterampilan proses sains peserta didik melalui sikap ilmiah yang diharapkan seluruh komponen sekolah (guru, siswa, masyarakat) memiliki kepedulian yang sama untuk mengembangkan potensi lokal. Guru selalu memunculkan potensi lokal pada setiap proses pembelajaran Fisika baik melalui contoh, penguatan, analisis persoalan, dan pemecahannya. Langkah inilah yang dilatih secara terus menerus akan mampu menumbuhkan dan meningkatkan soft skills yang baik pada diri siswa (Khoiri, 2014) Soft skill yang dimaksud keterampilan proses sains.

Peningkatan nilai aspek KPS terjadi dalam membiasakan keterampilanketerampilan proses dasar yang telah dimiliki selama pembelajaran, Diperkuat oleh mungmachon (2011) dan Mumpuni (2013) penggunaan pembelajaran berbasis potensi lokal sangat penting untuk meningkatkan keterampilan dan berdasarkan kehidupan nyata. Pembelajaran berulang melalui potensi lokal seni ukir jepara mampu memunculkan fanatisme yang kuat, motivasi, kecintaan, loyalitas, komitmen, kesungguhan, minat, kebermaknaan dan kreativitas, serta bagaimana mampu membekali keterampilanketerampilan proses sains secara maksimal.

Aspek "Mengamati" sampai dengan "menerapkan konsep" merupakan serangkaian aktivitas belajar Fisika melalui pemanfaatan potensi lokal seni ukir jepara, keseluruhan ide, fakta ataupun konsep pada materi pesawat sederhana diinterpretasikan dalam kegiatan pembuatan seni ukir Jepara yang berdasarkan Tabel 7.

Indikator keterampilan proses sains melalui aspek "Mengamati" menekankan keterampilan dalam mengumpulkan data atau informasi tentang seni ukir melalui media, buku-buku serta sumber lain dituntut untuk menggali segala bentuk informasi, setelah informasi diperoleh proses mengklasifikasikan objek berdasarkan fakta, pemilihan sumber informasi sebagai sarana belajar menghasilkan konsep pesawat sederhana, 


\section{Formatif: Jurnal Ilmiah Pendidikan MIPA}

Vol. 8, No. 1, April 2018, pp. 57-68

p-ISSN: 2088-351X

e-ISSN: 2502-5457

DOI: http://dx.doi.org/10.30998/formatif.v8i1.2365

merumuskan masalah yang dikaji yaitu alat yang digunakan untuk mengukir (lihat Tabel 7). Merumuskan hipotesis sebelum melakukan percobaan pada keterampilan seni ukir dengan menduga alat yang tepat digunakan untuk berbagai aktivitas mengukir seperti mempertimbangkan teknik dasar mengukir kayu yaitu, Teknik Chip (ukiran sendok) menggunakan pisau untuk menghilangkan serpihan kayu kecil dari panel atau blok, membuat pola ukiran dan Teknik ukir putaran (ukiran 3 dimensi), selanjutnya peserta didik mempersiapkan alat dan bahan percobaan untuk melakukan kegiatan mengukir setelah melakukan percobaan, peserta didik menganalisis dan menyimpulkan data percobaan sebagai acuan keberhasilan belajar melalui uji post test yang dilakukan setelah pembelajaran berlangsung (lihat Tabel 6). Adapun langkah pembelajaran yang dilakukan dalam pembelajaran Fisika berbasis potensi lokal dapat disajikan dalam tabel 8.

Tabel 7. Aspek Potensi Lokal dan Materi Pesawat Sederhana

\begin{tabular}{|c|c|c|c|c|c|}
\hline \multirow[t]{2}{*}{ Peralatan Seni Ukir } & \multirow[t]{2}{*}{ Fungsi Peralatan Ukir } & \multicolumn{4}{|c|}{$\begin{array}{r}\text { Aspek Materi } \\
\text { Pesawat Sederhana } \\
\end{array}$} \\
\hline & & $\mathrm{T}$ & $\mathrm{B} \mathrm{M}$ & $\mathrm{K}$ & $\mathrm{RB}$ \\
\hline Gunting & Memotong kertas pola ukiran & $\sqrt{ }$ & & & \\
\hline Tang & Mencabut paku & $\sqrt{ }$ & & & \\
\hline Penjepit Kayu & Menjaga kayu tidak goyah & $\sqrt{ }$ & & & \\
\hline Gerobak dorong & Mengangkut kayu sudah yang dipotong & $\sqrt{ }$ & & & \\
\hline Palu Kayu & Memberi gaya alat pahat & $\sqrt{ }$ & & & \\
\hline Alat pahat & Membentuk pola ukiran & & $\sqrt{ }$ & & \\
\hline Gergaji & Memotong kulit kayu & & $\sqrt{ }$ & & \\
\hline Kapak & Membelah kayu & & $\sqrt{ }$ & & \\
\hline Papan miring & $\begin{array}{l}\text { Memindahkan ukiran kayu yang berat ke } \\
\text { atas mobil }\end{array}$ & & $\sqrt{ }$ & & \\
\hline Katrol & Memindahkan balok kayu & & & $\sqrt{ }$ & \\
\hline Alat bobok kayu & $\begin{array}{l}\text { Membentuk pola ukiran yang lebih kecil } \\
\text { dan rumit }\end{array}$ & & $\sqrt{ }$ & & $\sqrt{ }$ \\
\hline
\end{tabular}

T: Tuas; BM: Bidang Miring; K: Katrol dan RB : Roda Berporos

Tabel 8. Kegiatan Pembelajaran Berbasis Potensi Lokal

\begin{tabular}{|c|c|c|}
\hline No & Kegiatan Guru & Kegiatan Peserta Didik \\
\hline 1 & $\begin{array}{l}\text { Memberikan apersepsi sebelum } \\
\text { pembelajaran dimulai. Apersepsi dikaitkan } \\
\text { dengan potensi lokal di Jepara }\end{array}$ & $\begin{array}{l}\text { Menanggapi apersepi yang diberikan } \\
\text { guru. }\end{array}$ \\
\hline 2 & Menjelaskan tujuan pembelajaran & Memahami tujuan pembejaran \\
\hline 3 & $\begin{array}{l}\text { Membagi peserta didik menjadi beberapa } \\
\text { kelompok dan membagikan LKPD yang } \\
\text { disajikan Potensi Lokal Jepara kepada } \\
\text { masing-masing peserta didik }\end{array}$ & $\begin{array}{l}\text { Berkelomnpok sesuai dengan kelompok } \\
\text { yang telah dibagi kemudian mengerjakan } \\
\text { LKPD yang disajikan Potensi Lokal } \\
\text { Jepara }\end{array}$ \\
\hline 4 & Menyiapkan alat dan bahan percobaan & Menyiapkan alat dan bahan percobaan \\
\hline 5 & $\begin{array}{l}\text { Memandu peserta didik melakukan } \\
\text { percobaan dan mengerjakan LKPD }\end{array}$ & $\begin{array}{l}\text { Melaksanakan percobaan dan } \\
\text { mengerjakan LKPD }\end{array}$ \\
\hline 6 & $\begin{array}{l}\text { Memberikan kesempatan peserta didik } \\
\text { untuk mengkomunikasikan hasil percobaan } \\
\text { dan mengerjakan LKPD }\end{array}$ & $\begin{array}{l}\text { Peserta didik mengkomukasikan hasil } \\
\text { percobaan dan hasil mengerjakan LKPD }\end{array}$ \\
\hline 7 & $\begin{array}{l}\text { Memberikan kesempatan peserta didik } \\
\text { untuk menyimpulkan hasil pembelajaran } \\
\text { pertemuan ini }\end{array}$ & $\begin{array}{l}\text { Menyimpulkan hasil pembelajaran } \\
\text { pertemuan hari ini. }\end{array}$ \\
\hline
\end{tabular}

Kegiatan pembelajaran yang dilaksanakan dalam setiap pertemuan mengidentifikasi keterampilan proses sains melalui materi pesawat sederhana, pesawat 
Formatif: Jurnal Ilmiah Pendidikan MIPA

Vol. 8, No. 1, April 2018, pp. 57-68

p-ISSN: 2088-351X

e-ISSN: 2502-5457

DOI: http://dx.doi.org/10.30998/formatif.v8i1.2365

sederhana merupakan alat untuk mempermudah dalam melakukan pekerjaan (usaha) para seni ukir yang memanfaatkan Tuas, Bidang miring, Katrol dan Roda Berporos. Sehingga peserta didik secara langsung dapat mengetahui dan menemukan serta melakukan percobaan pada kegiatan seni ukir sebagai laboratorium dan sarana belajar Fisika secara ilmiah yang dapat menumbuhkan keterampilan proses sains. Pembelajaran berbasis potensi lokal selalu mengaitkan materi dengan lingkungan keadaan nyata serta meningkatkan rasa kecintaan terhadap potensi yang dimiliki dan termotivasi untuk mempelajarinya (Tosun and Taskesenligil, 2011).

Berdasarkan Tabel 4 Keseluruhan aspek jiwa kewirausahaan peserta didik mempunyai rata-rata $83,3 \%$ kategori baik berupa percaya diri, berorientasi pada tugas dan hasil, berani mengambil risiko, berjiwa kepemimpinan, berpikir ke arah hasil (manfaat), dan keorisinilan. Sikap-sikap terbentuk karena peserta didik berada pada lingkungan yang memiliki bermacam-macam potensi lokal, memicu munculnya jiwa kewirausahaan. Seni ukir jepara memiliki nilai jual tinggi berupa percaya diri peserta didik untuk mempertahankan warisan budaya nenek moyang serta dapat meningkatkan eksistensi dan keberlangsungan para wirausaha seni ukir. Potensi lokal yang telah dipelajari memunculkan jiwa fanatisme dan loyalitas tinggi dengan rasa kepemilikan yang kuat selanjutnya memunculkan sikap jiwa kewirausahaan untuk mengembangkan dan mengoptimalkan seni ukir. Keberadaan potensi lokal merupakan hasil proses adaptasi dan interaksi antar lingkungan satu dengan yang lain serta membutuhkan waktu yang lama tidak simultan atau singkat (Hagi P.J, et.al. 2013). Peserta didik setidaknya telah mempelajari seni ukir sebagai bekal dan pengetahuan untuk mempersiapkan masa depannya dalam menekuni warisan budaya seni ukir.

Peserta didik SMP 6 Jepara meskipun sebagai generasi muda yang masih jauh dengan dunia usaha, tetapi setidaknya dengan pembelajaran yang berorientasi potensi lokal dapat membekali pengetahuan tentang potensi-potensi yang dapat dijadikan tolak ukur dan acuan dalam mengembangkan potensi daerah Jepara. Berdasarkan hasil angket (lihat Tabel 4) setidaknya mempunyai gambaran awal dalam membangun jiwa kewirausahaan melalui indikator "Berorientasi pada tugas dan hasil" memiliki persentase paling tinggi. Sikap yang terbentuk dengan menemukan hal-hal baru dalam mengembangkan potensi lokal Jepara lebih kreatif, prospektif, dan memberi keuntungan untuk warga Jepara. Aspek "berani mengambil risiko" persaingan pasar antar daerah lokal mapun nasional semakin bervariatif, berani mengambil resiko, dan siap menghadapi tantangan jaman demi keberlangsungan seni ukir jepara. Pada "jiwa kepemimpinan" peserta didik mempunyai sikap terbuka terhadap saran dan kritik untuk pengembangan potensi lokal Jepara menjadi lebih baik, sikap bijaksana menjadi bagian terpenting dalam jiwa kepemimpinan bukan sebagai penguasa pasar, namun pemimpin yang dapat menyejahterakan dan memberdayakan masyarakat jepara dalam kaitannya terhadap seni ukir. Sedangkan "berpikir ke arah hasil" hasil berkualitas tidak terlepas dari proses yang maksimal, ekstrakurikuler mengukir yang mengasah keterampilan peserta didik penting untuk dipelajari. Selain itu, persaingan pengembangan potensi lokal mendorong peserta didik lebih kreatif dan inovatif agar tidak tergerus persaingan usaha yang semakin ketat. Tingkat "keorisinilan" dan karakteristik seni ukir menjadi produk unggulan Kabupaten Jepara tidak terdapat di daerah lain, ciri khas produk sebagai wujud keorisinilan yang tidak dapat ditiru. 
Formatif: Jurnal Ilmiah Pendidikan MIPA

Vol. 8, No. 1, April 2018, pp. 57-68

p-ISSN: 2088-351X

e-ISSN: $2502-5457$

DOI: http://dx.doi.org/10.30998/formatif.v8i1.2365

\section{PENUTUP}

Berdasarkan hasil dan pembahasan, maka dapat disimpulkan bahwa:

1. Pembelajaran Fisika berbasis potensi lokal pada materi pesawat sederhana sebagai sumber belajar dalam penggunaan peralatan seni ukir dijelaskan melalui tuas, bidang miring, katrol, dan roda berporos yang memberikan kontribusi positif pada keterampilan proses sains dan minat jiwa wirausaha peserta didik.

2. Berdasarkan hasil uji t sampel berkorelasi dan uji gain $\left(\mathrm{t}_{\text {hitung }}<\mathrm{t}_{\text {tabel }}=0.0057<\right.$ 2.00) terdapat perbedaan Keterampilan Proses Sains sebelum dan sesudah pembelajaran Fisika berbasis potensi lokal dan peningkatan sebesar 0.347 berkategori sedang.

3. Berdasarkan perhitungan persentase aspek jiwa kewirausahaan diperoleh; 1) percaya diri $(90.42 \%)$; 2) berorientasi pada tugas dan hasil (88.89\%) 3) berani mengambil risiko $(88.89 \%)$; 4) berjjiwa kepemimpinan $(81.25 \%)$ 5) berfikir ke arah hasil (manfaat) (66.324\%), dan 5) keorisinilan (84.03\%). Pembelajaran berbasis potensi lokal membekali pengetahuan tentang potensi-potensi yang dapat dijadikan tolak ukur dan acuan dalam mengembangkan potensi daerah Jepara.

\section{DAFTAR PUSTAKA}

Aniesa, A. (2016) "Potensi Lokal Sebagai Dasar Pengembangan Perangkat Pembelajaran di IPA SMP Untuk Meningkatkan Keterampilan Berpikir Kritis dan Sikap Kewirausahaan Peserta Didik”. Thesis Magister, Progam Pasca Sarjana UNY.

Arikunto, S. (2010). Prosedur Penelitian Suatu Pendekatan Praktik. Jakarta: Rineka Cipta.

Badan Penelitian dan Pengembangan Pusat Kurikulum (BPPPK). (2010). Pengembangan Pendidikan Kewirausahaan. Jakarta: Kementerian Pendidikan Nasional.

Badan Penelitian dan Pengembangan Pusat Kurikulum. (2010). Pengembangan Pendidikan Kewirausahaan. Jakarta: Kementerian Pendidikan Nasional.

BAPPEDA Jepara. (2009). Legenda Jepara. PemKab Jepara.

BBMPT Jepara. (2012). Profil Investasi Kabupaten Jepara 2012. Jepara: BBMPT.

BSNP. (2006). Standar Kompetensi dan Kompetensi Dasar SMP/MTs. Jakarta: BSNP.

Dewi, Shinta. (2009). Keterampilan Proses Sains. Bogor: Regina.

Dimyati dan Mudjiono. (2009). Belajar dan Pembelajaran. Jakarta: Rineka Cipta.

Fajar M, Hendra. (2015). Potensi lokal sekolah PAUD sebagai media pembelajaran berbasis konstsruktivisme. Prosiding ISBN:978-602-99975-1-4 Semnas Sains \& Entrepreneurship II Agustus 2015 Hal:246-255

Hagi P.J, et.al. (2013). Kajian profil kearifan lokal masyarakat pesisir Pulau Gili Kecamatan Sumber Kabupaten Probolinggo Jawa Timur. Jurnal ECSOFiM. 1 (1): $11-25$.

Halimah, I. (2006). Pengelolaan pembelajaran berbasis potensi lokal di PKBM. Jurnal Mimbar Pendidikan, 1 (2): 39-45.

Kabupaten Jepara. 2011. Peraturan Daerah Kabupaten Jepara Nomor 1 Tahun 2011 Tentang Pengelolaan dan Penyelenggaraan Pendidikan. Jepara: Pemkab Jepara.

Khoiri, A. (2014). Pengembangan bahan ajar fisika SMK berbasis potensi lokal untuk menumbuhkan soft skills Siswa. Journal of Innovative Science Education, 3 (1).

Khoiri, A. (2016). Local wisdom PAUD to grow student's soft skills (Case Study: Development RKH on Science Learning. Indonesian Journal of Early Childhood Education Studies, 5 (1): 14-17. 
Formatif: Jurnal Ilmiah Pendidikan MIPA

Vol. 8, No. 1, April 2018, pp. 57-68

p-ISSN: 2088-351X

e-ISSN: 2502-5457

DOI: http://dx.doi.org/10.30998/formatif.v8i1.2365

Leo Agung, S. (2015). The development of local wisdom-based social science learning model with Bengawan Solo as the learning source. American International Journal of Social Science, 4 (4): 51-58.

Mumpuni, E. K. (2013). Potensi Pendidikan Keunggulan Lokal Berbasis Karakter dalam Pembelajaran Biologi di Indonesia. Makalah. Seminar Nasional X FKIP di Universitas Negeri Surakarta. Surakarta 16 Mei.

Mungmachon, M. R. (2012). Knowledge and local wisdom: Community treasure. International Journal of Humanities and Social Science, 2 (13): 174-181.

Murianews Reporter. (2016). Tukang Ukir dan Kayu di Jepara Dilanda Galau. 28 September 2015. www.murianews.com/2015/09/28/53599/tukiang-ukir-dan-kayudi-jepara-dilanda-galau.html (11 November 2016).

Prasetyo, Z. K. (2013). Pendidikan Berbasis Kearifan Lokal. Makalah. Seminar Nasional Sains dan Pendidikan Sains di Univeristas Negeri Surakarta. Surakarta 14 Maret.

Priyatno Hadi. (2016). Pelestarian Ukir Jepara.. Suara Merdeka 24 Mei 2014, http://www.suaramerdeka.com/v1/index.php/read/cetak/2014/05/24/262458/Peles tarian-Ukir-Jepara (30 November 2016).

Priyatno, Hadi. (2013). Mozaik Seni Ukir. Semarang: Surya Offset.

Sugiyono. (2010). Statistika untuk Penelitian. Bandung: Alfabeta.

Sugiyono. (2015). Metode Penelitian Pendidikan Pendekatan Kuantitatif, Kualitatif dan $R \& D$. Bandung: Alfabeta.

Sukardi. (2016). Nguri-Nguri Ruh Sekolah Teknik. Harian Suara Muria Suara Merdeka, 5 Oktober 2016.

Suparyanto, R.W. (2013). Kewirausahaan Konsep dan Realita pada Usaha Kecil. Bandung: Alfabeta.

Tosun, C., \& Tapkesenlýgýl, Y. (2012). The effect of problem based learning on student motivation towards chemistry classes and on learning strategies. Journal of Turkish Science Education, 9(1), 104-125. 